\title{
PENERAPAN SISTEM INFORMASI MANAJEMEN PADA LEMBAGA PENDIDIKAN
}

\author{
Azizah \\ Azizahcaniago77@gmail.com
}

\begin{abstract}
Abstrak
Tujuan dari penulisan artikel ini adalah untuk menjelaskan mengenai penerapan system informasi manajemen pada lembaga pendidikan, yang mana didalamnya dibahas mengenai pengertian sisitem informasi manajemen, tujuan dan manfaat system informasi manajemen, karakteristik system informasi manajemen, dan system informasi manajemen pendidikan pada lembaga pendidikan yang mana kita dapat mengetahui apasaja penerapan dari system infromasi manajemen ini pada lembaga pendidikan, yang dimulai dari pengolah data sampai pemrograman data.
\end{abstract}

Kata Kunci : Sistem informasi manajemen, lembaga pendidikan

\section{PENDAHULUAN}

System informasi manajemen adalah suatu penerapan atau implementasi dari suatu system yang biasanya digunakan oleh masyarakat. Setiap individu dalam suatu organisasi pasti memiliki suatu posisi atau jabatan dan juga lingkup pekerjaan yang mana individu bertugas melakukan manajemen atau pengaturan, pentaan dan pengelolaan pada suatu divisi atau bagian dalam organisasi atau perusahaan, yang mana itu kita sebut sebagai kalangan manajerial.

Individu yang fungsinya dapat mengatur dan mengelola atau memanage bawahannya, untuk itu system informasi manajemen ini sangat penting untuk manajemen, terutama manajemen pendidikan, contohnya saja dengan adanya system informasi manajemen ini dapat memudahkan manager dalam melakukan monitoring terhadap kinerja anak buah atau karyawannya,memberikan penilaian, baik penilaian langsung maupun tidak langsung terhadap kinerja bawahannya, dapat melihat dimana kelebihan ataupun kelemahan dari karyawannya, membantu mempercepat proses pengambila keputusan oleh manajer dalam mengatai suatu masalah, selain itu system informasi manajemen juga dapat meningkatkan efisiensi manajerial di dalam suatu organisasi atau perusahaan, dll.

Suatu system informasi mencakup kegiatan pengumpulan, pengorganisasian, 
dan pendistribusian data sedemikian rupa sehingga dat tersebut menjadi infromasi yang bermakna bagi pengambila keputusan (Machmud: 2013)

\section{PEMBAHASAN}

\section{A. Sitem Informasi Manajemen}

1. Pengertian system informasi manajemn

Menurut Muladi (2008), dalam (MACHMUD, 2013) system adalah sekelompok dua atau lebih komponenkomponen yang saling berkaitan ( subsistem- subsistem ang bersatu untuk mencapai tujuan yang sama). Sedangkan menurut Kusrini ( 2007), informasi adalah data yang sudah diolah menjadi sebuah bentuk yang berguna bagi pengguna yang bermanfaat dalam pengambilan keputusan saat ini atau mendukung sumber informasi.

Sedangkan menurut Husain dan Wibowo dalam (MACHMUD, 2013), system informasi adalah seperangkat komponen yang salin berhubungan yang berfungsi mengumpulkan, memproses, menyimpan, dan mendistribusikan informasi untuk mendukung pembuatan keputusan dan pengawasan organisasi. Menurut Azhar Susanto (2008), dalam (MACHMUD, 2013) system informasi adalah kumpulan dari subsistem apapun baik phisik ataupun nonphisik yang saling berhubungan satu sama lain dan bekerja sama secara harmonis untuk mencapai satu tujuan aitu mengolah data menjadi informasi ang berarti dan berguna.

Menurut Sastradipora(MACHMUD, 2013)), system informasi manajemen adalah serangkaian sub-sistem infromasi yang menyeluruh dan terkoordinasi dan secra rasional terpadu dalam mentranformasi data, sehingga menjadi informasi melalui serangkaian cara untuk meningkatkan produktivitas sesuai dengan gaya dan sifat manajer atas dasar criteria mutu yang telah ditetapkan.

(Dewi, 2006) system infromasi manajemen adalah suatu metode untuk menhasilkan informasi manajemen tentang lingkungan luar organisasi, dengan tujuan untuk menunjang prosesnpengambilan keputusan serta memperbaiki proses perencanaan dan pengawasan. Oleh karena itu dengan adanya system informasi manajemen pada suatu sekolah dapat mempermudah kinerja guru untuk menghasilkan mutu pendidikan yang lebih berkualitas lagi.

System infromasi manajemen menurut (AHMAD, 2017) adalah sebuah metode formal untuk mneyediakan infromasi yang akurat dan tepat waktu bagi manajemn yang diperlukan untuk mempermudah proses pengambilan keputusan dan memungkinkan fungsifungsi dari manajemen seperti perencanaan, 
pengendalian, operasional organisasi dapat dilaksanakan secra efektif.

Jadi system informasi manajemen menurut (MACHMUD, 2013) adalah seluruh rangkaian aktivitas kerja system infomrasi yang membentuk satu kesatuansistem dengan tujuan ang sama melalui proses pengumpulan, penyimpanan, pengolahan samapai akhirnya menghasilkan informasi yang berguna bagi seluruh anggota organisasi (pemimpin dan staff) untuk membuat kebijakan atau menetukan keputusan menjadi lebih baik berkenaan dengan kepentingan organisasi.

2. Manfaat dan Tujuan Sistem Informasi Manajemen

Manfaat yang dapat diperoleh dari system informasi dapat diklasifikasikan sebgai berikut dalam (Aswati, 2015), yaitu

a. Mengurangi biaya,

b. Mengurangi kesalahan - kesalahan.

c. Meningkatkan kecepatan aktifitas,

d. Meningktakan perencanaan dan pengendalian manajemen,

Sedangkan dalam bentuk terwujud (Aswati, 2015) Pengurangan biayabiaya opeasi,

a. Pengurangan kesalahan, kesalahan,

Dan yang tidak terwujud, yaitu: (Aswati, 2015) yaitu:

a. Peningkatan pelayanan lebih baik,

b. Peingkatan kepuasan keerja personil,

c. Peningktana pengambilan keputusan, dll.
Tujuan system informasi manajemen (AHMAD, 2017) adalah suapay organisasi memilki suatu system ang dapt diandalkan dlam mengolah data menjadi infromasi yang bermanfaat dalam pembuatan keputusan manajemen, baik yang menangkut keputusankeputusan rutin atau keputusan startegik, selain itu juuga dapat digunakan sebgaai pendukung kegiatan fungsi manajemen dalam rangka menunjang tercapaina sasaran dan fungsi- fungsi operasional dalam organisasai pendidikan.

3. Karakterisk Sistem Informasi Manajemen Berdasarkan beberapa pengertian diatas maka dapat diketahu bebrapa karakterisktik diantaranya(AHMAD, 2017) :

a. Dalam suatu organisasi terdapat suatu bagian khusus sebagai pengelola system infromasi manajemen.

b. System infromasi manajemen merupakan jalinan lalu lintas data dan infromasi sari setiap bagian didalam organisasi yangterpusat dibagain system informasi manajemen.

c. System informasi manajemen merupakan jainana hubungan anatar bagian dalam organisasi melalui satu bagian system informasi manajemen.

d. Sistem informasi manajemen menrupakan segenap proses yang mencakup pengumpulan data, 
pengolahandata, penyimpanan data, pengambilan data, dan penyebaran infromasi dengan cepat dan tepat.

e. Sistem infromasi manajemen bertujuan agar pelaksana dapat melaksnakan tugas dengan baik dan benar serta pimpinana dapat membauta keputusan dengan cepat dan tepat.

B. Sistem Informasi Manajemen Pendidikan pada Lembaga Pendidikan

(Darwis, 2017), system infromasi manajemen pendidikan adalah perpaduan antara sumber daa manusia dan aplikasi teknologi informasi untuk memilih, menyimpan, mengolah dan mengambil kembali data dalam rangka mendkung proses pengambila keputusan bidang pendidikan. dan system informasi manajemen pendidikan adalah suatu kumpulan dari komponen ang saling berkaitan, ang diatur, dikelola atau dikoordinasikan untuk mengubah datamenjkadi informasi guna mencapai tujuan pendidikan.

1. Nilai Penting Sistem Informasi Manajemen

(AHMAD, 2017), mengemukakan ada beberapa nilai penting system informasi manajemen, diatarana:

a. System informasi yang berbasis computer memungkinkan pendelegasian kegiatan rutin. b. Teknologi informasi memungkinkan pengolahan dan secra lebih akurat dan handal.

c. Pembuatan keputusan akan ditunjang dengan pilihan alternative yang lebih objektif dengan data pendukung ang lengkap.

d. Monitoring dan evaluasi memerlukan penerapan informai secara cepat dan efesien.

2. Bidang Sistem Infomasi Manajemen System informasi manjemen merupakan suatu badan yang memiliki tugas- tugas tertentu. Bagian, (AHMAD, 2017), ada bebrapa bidang sisitem infromasi manajemen yang digunakan pada lemabaga pendidikan, dianataranya:

a. Bidang pengumpulan data

Dalam mengumpulkan data, baik bersifat internal merupakan data yang berasal dari dlam organisasi, sedangkan data eksternal merupakan data yang berasal dari luar organisasi namun asih dapat hubungan dengan perkembangan organisasi. Personalia yang bertugas pada pengumpulan data dapat diambilkan dari seluruh unit kerja dalam organisasi yaitu wakasek, sehingga setiap unit kerja memilki wakil- wakil untuk menunjang keefektifan pengumpulan data untuk 
diolah menjadi sebuah infromasi yang bermafaat bagi pengguna infromasi.

b. Bagian penyimpanan

Bagian penimpanan dan bertugas menyimpan data. Penimpanan data sangat diperlukan karena tujuan utama adalah demi keamanan data. Apabial level- level manajemen membutuhkan data, baik berupa data bahan mentah amupun data yang telah diolah, maka dat dapat diambil dan digunakan sesai engan kebutuhan manajer atau ekpa sekolah.

c. Bagian pengolahan data

Bagian inin bertugas memproses data dengan mengikiti serangkaian langkah atau pola tertentu sehingga dapat dirubah ke dalam bentuk informasi yang lebi berguna. Pada pemrosesan data bisa dilakuakan secra manual maupun dengan bantuan mesin. Bagian pemrosesan data terdiri beberapa ahli yang bertugas membentuk data menjadi informasi yang sesuai dengan kebutuhan suatu sekolah.

d. Bagian pemrograman data

Apabila suatu sekolah telah memiliki perangkatak computer, maka bagian pemrograman data disebut programmers, yiatu kelompok ahli yang bertanggung jawab atas penususnan program untuk diberikana kepada perangkat computer. Karen akomuter meimilki tingkat bahasan tersendiri.

\section{PENUTUP}

\section{Kesimpulan}

Berdasarkan materi diatas maka dapat disimpulkan system informasi manajemen menurut (MACHMUD, 2013) adalah seluruh rangkaian aktivitas kerja system infomrasi yang membentuk satu kesatuansistem dengan tujuan ang sama melalui proses pengumpulan, penyimpanan, pengolahan samapai akhirnya menghasilkan informasi yang berguna bagi seluruh anggota organisasi (pemimpin dan staff) untuk membuat kebijakan atau menetukan keputusan menjadi lebih baik berkenaan dengan kepentingan organisasi.

System informasi manajemen ini memilki beberapa manafaat (Aswati, 2015), seperti mengurangi biaya, mengurangi kesalahankesalahan, meningkatkan kecepakan aktifitas, meningktaknan perencanaan pengendalian manajemen. Tujuan system informasi manajemen (AHMAD, 2017), adalah suapay organisasi memilki suatu system ang dapt diandalkan dlam mengolah data menjadi infromasi yang bermanfaat dalam pembuatan keputusan manajemen, baik yang menangkut 
keputusan- keputusan rutin atau keputusan startegik.

System informasi manajemen ini sangat berguna bagi lembaga pendidikan ang man dapat membatu sekolah atau lembaga pendidikan, mulai dari pengumpulan data, penyimpanan data, pengolah data dan pemrograman data.

\section{DAFTAR PUSTAKA}

AHMAD, L. O. I. D. R. S. (2017). Penerapan Sistem Informasi Manajemen Pendidikan Dalam Proses Pembelajaran Di Smp Negeri 21 Makassar. Jurnal Idaarah, 1, 290-309. Retrieved from http://journal.uinalauddin.ac.id/index.php/idaarah/a rticle/download/4272/3934

Aswati, S. dkk. (2015). Peranan Sistem Informasi Dalam Perguruan Tinggi. Retrieved from https://scholar.google.co.id/schola $\mathrm{r}$ ?hl=id\&as_sdt $=0 \% 2 \mathrm{C} 5 \& \mathrm{q}=$ peran +sistem+informasi+dalam+pergur uan+tinggi\&oq=peran+sistem + inf ormasi+dalam+perguruan $+\mathrm{t} \# \mathrm{~d}=\mathrm{gs}$ _qabs\&u=\%23p\%3DvSWB41Cqv oYJ

Darwis, A. (2017). Sistem Informasi Manajemen Pada Lembaga Pendidikan Islam. Journal of Islamic Education Management, 2, 64-77. Retrieved from https://scholar.google.co.id/schola $\mathrm{r}$ ?hl=id\&as_sdt $=0 \% 2 \mathrm{C} 5 \& \mathrm{q}=$ pener apan+sistem+informasi+manajem en+pada+lembaga+pendidikan\&bt $\mathrm{nG}=\# \mathrm{~d}=\mathrm{gs} \_\mathrm{qabs} \& \mathrm{u}=\% 23 \mathrm{p} \% 3 \mathrm{D} 5 \mathrm{jf}$ YhaDK6BMJ

Dewi, A. P. dan A. S. (2006). Persepsi Guru Dalam Meningkatkan Mutu
Pendidikan Berbasis Sistem Informasi MANAJEMEN DI SEKOLAH DASAR NEGERI 08 Batang Anai. Retrieved from https://scholar.google.co.id/schola r?hl=id\&as_sdt $=0 \% 2 C 5 \& q=$ siste m+informasi+manajemen+Ahmad +sabandi\&oq=\#d=gs_qabs\&u=\%2 $3 \mathrm{p} \% 3 \mathrm{DpKNfMYhPVIEJ}$

MACHMUD, R. (2013). Peranan Penerapan Sistem Informasi Manajemen Terhadap Efektivitas Kerja Pagawai Lembaga Pemasyarakatan Narkotika (Lapastika) Bollangi Kabupaten Gowa. Jurnal Capacity STIE AMKOP Makassar, 9, 409-421. Retrieved from https://scholar.google.co.id/schola $\mathrm{r}$ ?hl=id\&as_sdt=0\%2C5\&q=peng ertian+sistem+informasi+manaje men\&oq=pengertian+sistem+infor masi + mana\#d=gs_qabs\&u $=\% 23 p$ \%3DXhT0BEngIIYJ 